\title{
Data update for Vietnam economics research institutions as of October 2021
}

\author{
Quang-Loc Nguyen \\ SP Jain School of Global Management \\ New South Wales 2141, Australia
}

Research data in Vietnam have been fragmented, and this is a long-standing fact. Although several universities repeatedly claim that they have been the leading players in economics research, actual data may not support their claims.

In a recent attempt, Dr. Le Van Ut of Ton Duc Thang University in Ho Chi Minh City compiled a data set to figure out Vietnamese scholars' internal capacity. Nonetheless, this report covers too large a spectrum that economics research has little weight. In fact, only one person represents the humanities and social sciences in Dr. Ut's 22-person lifetime achievement list, and only a handful in his 2021 most influential list [1].

\section{jIDEAS Economic literature Authors Institutions Rankings Help/FAQ}

y $f$ in $\square \theta$

Top 25\% Institutions and Economists in Viet Nam, as of October 2021

\begin{tabular}{|l|l|l|l|l|l|l|l|l|l|l|l|}
\hline Explanations & Institutions & Institutions 10/10 & Authors & Authors 10 & More \\
\hline
\end{tabular}

The rankings

Top 25\% institutions in Viet Nam, all authors, all publication years

For Viet Nam, there are 191 authors affiliated with 58 institutions. All institutions in this region.

\begin{tabular}{|c|c|c|c|c|c|}
\hline \multicolumn{2}{|c|}{ Rank W.Rank } & \multirow[b]{2}{*}{$\begin{array}{l}\text { University of Economics Ho Chi Minh City } \\
\text { Ho Chi Minh City, Viet Nam }\end{array}$} & \multicolumn{2}{|c|}{ ScoreAuthors } & \multirow{2}{*}{$\begin{array}{r}\begin{array}{r}\text { Author } \\
\text { shares }\end{array} \\
14.2\end{array}$} \\
\hline 1 & [1] & & 1.51 & 17 & \\
\hline 2 & [2] & $\begin{array}{l}\text { Centre for Interdisciplinary Social Research, Phenikaa University } \\
\text { Hanoi, Viet Nam }\end{array}$ & 3.31 & 11 & 10.15 \\
\hline 4 & [4] & $\begin{array}{l}\text { Department of Social Sciences, Economics and Management, International } \\
\text { School, Vietnam National University } \\
\text { Hanoi, Viet Nam }\end{array}$ & 3.95 & 6 & 2.56 \\
\hline
\end{tabular}


URL: https://ideas.repec.org/top/top.vietnam.html

Perhaps, the only database available for comparing economics and management research institutions in terms of scientific impact is the IDEAS RePEc, one that has been managed and maintained by the Research Division of the Federal Reserve Bank of St. Louis, USA. The most recent update for Oct-2021 is out today [2]. The IDEAS provides rankings for both institutions and individual contributing authors as members of institutions. (The two rankings are given in the appendix of this short piece.)

There are two noteworthy observations while trying to learn from the IDEAS data.

Firstly, the list of the top 25\% of economics research institutions in Vietnam as of October 2021 contains almost all well-known players in the field. The order is somewhat surprising, with the two perhaps most famous ones, i.e., Central Institution for Economic Management (CIEM) and National Economics University (NEU), being in the last two positions of the 14 best-performing institutions. The youngest player in the list (i.e., the Centre for Interdisciplinary Social Research of Phenikaa University) has a very high position, No. 2, only behind the University of Economics Ho Chi Minh City (UEH).

Secondly, all the people who appear on Dr. Ut's 65-author list also belong to the IDEAS topperforming author list, e.g., Vo Xuan Vinh (top male) and Le Thai Ha (top female). And I trust that this fact is most probably not accidental. In other words, both data sets by Dr. Ut (Scopus and Web of Science) and IDEAS (RePEc) have been in handsome agreement.

For me, both data sets are very important because they provide insights from different viewing angles. In addition, their agreement can also unveil interesting understanding and reconfirm each other's value.

\section{References}

[1] Út, L. V. (2021). Sự thật về nội lực Việt Nam trong trích dẫn khoa học hàng đầu thế giới 2021. Dân Trí (Oct. 30). Retrieved from: https://dantri.com.vn/giao-duc-huong-nghiep/suthat-ve-noi-luc-viet-nam-trong-trich-dan-khoa-hoc-hang-dau-the-gioi-202120211030083557165.htm (accessed: Nov. 7, 2021).

[2] IDEAS. (2021). Top 25\% Institutions and Economists in Viet Nam, as of October 2021. RePEc. Retrieved from: https://ideas.repec.org/top/top.vietnam.html (accessed: Nov. 7 , 2021) 


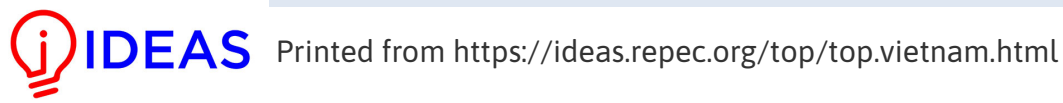

\section{Top 25\% Institutions and Economists in Viet Nam, as of October 2021

\begin{tabular}{|c|c|c|c|c|c|}
\hline Explanations & Institutions & Institutions 10/10 & Authors & Authors 10 & More \\
\hline
\end{tabular}

\section{The rankings}

Top 25\% institutions in Viet Nam, all authors, all publication years

For Viet Nam, there are 191 authors affiliated with 58 institutions. All institutions in this region.

\begin{tabular}{|c|c|c|c|c|c|}
\hline \multicolumn{2}{|c|}{ Rank W.Rank } & \multirow{2}{*}{$\begin{array}{l}\text { Institution } \\
\text { University of Economics Ho Chi Minh City } \\
\text { Ho Chi Minh City, Viet Nam }\end{array}$} & \multicolumn{2}{|c|}{ Score Authors } & \multirow{2}{*}{$\begin{array}{r}\text { Author } \\
\text { shares } \\
14.2\end{array}$} \\
\hline 1 & [1] & & 1.51 & 17 & \\
\hline 2 & [2] & $\begin{array}{l}\text { Centre for Interdisciplinary Social Research, Phenikaa University } \\
\text { Hanoi, Viet Nam }\end{array}$ & 3.31 & 11 & 10.15 \\
\hline 3 & [3] & $\begin{array}{l}\text { Mekong Development Research Institute } \\
\text { Hanoi, Viet Nam }\end{array}$ & 3.38 & 10 & 8.85 \\
\hline 4 & [4] & $\begin{array}{l}\text { Department of Social Sciences, Economics and Management, International School, Vietnam } \\
\text { National University }\end{array}$ & 3.95 & 6 & 2.56 \\
\hline--- & {$[--]$} & $\begin{array}{l}\text { Institute of Business Research, University of Economics Ho Chi Minh City } \\
\text { Ho Chi Minh City, Viet Nam }\end{array}$ & 4.51 & 4 & 4 \\
\hline 5 & [7] & $\begin{array}{l}\text { Foreign Trade University } \\
\text { Hanoi, Viet Nam }\end{array}$ & 5.65 & 10 & 8.89 \\
\hline 6 & [5] & $\begin{array}{l}\text { University of Economics, University of Danang } \\
\text { Danang, Viet Nam }\end{array}$ & 6.06 & 26 & 25.9 \\
\hline 7 & [6] & $\begin{array}{l}\text { Business and Economics Research Group, Ho Chi Minh City Open University } \\
\text { Ho Chi Minh City, Viet Nam }\end{array}$ & 6.94 & 11 & 10.5 \\
\hline 8 & [9] & $\begin{array}{l}\text { University of Economics and Business, Vietnam National University } \\
\text { Hanoi, Viet Nam }\end{array}$ & 9.01 & 5 & 4.9 \\
\hline --- & {$[---]$} & $\begin{array}{l}\text { School of Public Finance, University of Economics Ho Chi Minh City } \\
\text { Ho Chi Minh City, Viet Nam }\end{array}$ & 9.3 & 4 & 3 \\
\hline 9 & [8] & $\begin{array}{l}\text { School of Business and Management, RMIT University Vietnam } \\
\text { Ho Chi Minh City, Viet Nam }\end{array}$ & 9.31 & 6 & 6 \\
\hline 10 & [10] & $\begin{array}{l}\text { School of Public Policy and Management, Fulbright University Vietnam } \\
\text { Ho Chi Minh City, Viet Nam }\end{array}$ & 9.59 & 1 & 0.95 \\
\hline 11 & {$[11]$} & $\begin{array}{l}\text { Faculty of Economics and Public Management, Ho Chi Minh City Open University } \\
\text { Ho Chi Minh City, Viet Nam }\end{array}$ & 10.31 & 8 & 7.5 \\
\hline 12 & {$[12]$} & $\begin{array}{l}\text { Development and Policies Research Center (Depocen) } \\
\text { Hanoi, Viet Nam }\end{array}$ & 14.1 & 5 & 3.6 \\
\hline 13 & [13] & $\begin{array}{l}\text { Central Institution for Economic Management (CIEM) } \\
\text { Hanoi, Viet Nam }\end{array}$ & 15.93 & 2 & 2 \\
\hline 14 & {$[14]$} & $\begin{array}{l}\text { National Economics University } \\
\text { Hanoi, Viet Nam }\end{array}$ & 17.06 & 8 & 6.5 \\
\hline
\end{tabular}

We do our best, but we cannot exclude errors.

IDEAS is a RePEc $\llbracket$ service hosted by the Research Division $\llbracket 7$ of the Federal Reserve Bank of St. Louis $\square$. RePEc uses bibliographic data supplied by the respective publishers. 


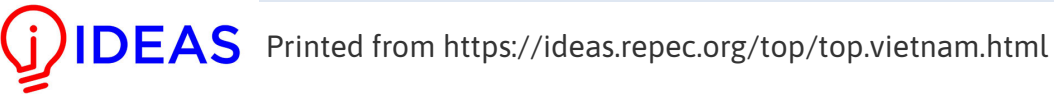

\section{Top 25\% Institutions and Economists in Viet Nam, as of October 2021}

\begin{tabular}{|l|l|l|l|l|l|}
\hline Explanations & Institutions & Institutions 10/10 & Authors & Authors 10 & More \\
\hline
\end{tabular}

\section{The rankings}

Top 25\% authors in Viet Nam, all publications years

For Viet Nam, there are 191 authors affiliated with 58 institutions. All institutions in this region.

RankW.Rank Author

Score

1. Cuong Viet Nguyen 1 [2] Department of Social Sciences, Economics and Management, International School, Vietnam National University, Hanoi 1.42

2 [3] $\frac{\text { Xuan Vinh Vo }}{\text { Institute of Business Research, University of Economics Ho Chi Minh City, Ho Chi Minh City }} 2.49$

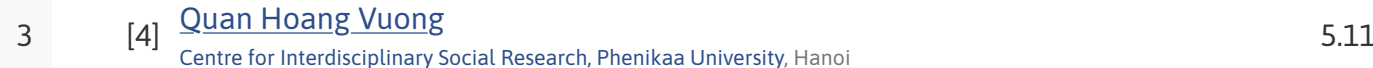

4 [8] $\frac{\text { Thai-Ha Le }}{\text { School of Public Policy and Management, Fulbright University Vietnam. Ho Chi Minh City }} 5.86$

5 [14] ㅌguyen Phu Ha 6.71

6 [15] Thuy Thu Nguyen 6.99

$7 \quad[6] \quad \begin{aligned} & \text { Duc Hong Vo } \\ & \text { Business and Economics Research Group, Ho Chi Minh City O_pen University, Ho Chi Minh City }\end{aligned}$

8 [9] $\frac{\text { Canh Phuc Nguyen }}{\text { School of Public Finance, University of Economics Ho Chi Minh City, Ho Chi Minh City }} 8.53$

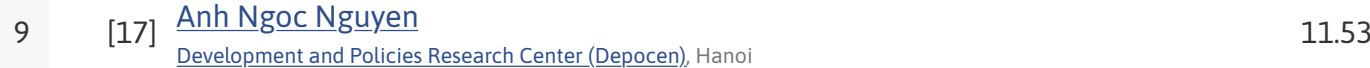

10 [12] $\frac{\text { Tuyen Quang Tran }}{\text { Department of Social Sciences, Economics and Management, International School, Vietnam National University, Hanoi }} 11.82$

11 [13] Thanh Dinh Su 11.85 School of Public Finance, University of Economics Ho Chi Minh City, Ho Chi Minh City

12 [23] Tung Lam Dang 12.45

13 [7] Toan Luu Duc Huynh 12.9

14 [21] $\frac{\text { Kien Le }}{\text { Faculty of Economics and Public Management, Ho Chi Minh City O_pen University, Ho Chi Minh City }} \underline{12.92}$

15 [26] $\frac{\text { Tung Duc Phung }}{\text { Mekong Development Research Institute, Hanoi }}$

16 [1] Duc Khuong Nguyen 15.27

17 [18] $\frac{\text { Tung Manh Ho }}{\text { Centre for Interdisciplinary Social Research, Phenikaa University Hanoi }} 19.02$

18 [29] Anh Duc Dang 19.17

19 [24] My Tra Nguyen

20 [10] Ho Manh Toan 20.46 
[25] Tuan Van Nguyen

[35] Vu Hoang Nam

[36] Huy Nguyen Anh Pham

[16] Shahaboddin Shamshirband Sr.

[41] Thi Thu Tra Pham School of Business and Management, RMIT University Vietnam, Ho Chi Minh City

[33] Hong Kong To Nguyen Centre for Interdisciplinary Social Research, Phenikaa University, Hanoi

[43] Dat Thanh Nguyen University of Economics, University of Danang, Danang

[30] Quoc Trung Tran Foreign Trade University, Hanoi

[22] Minh Ha Nguyen Business and Economics Research Group, Ho Chi Minh City Open University, Ho Chi Minh City

[38] Long Thanh Giang

[28] Ly Dai Hung

Vietnam Institute of Economics, Vietnam Academy of Social Sciences, Hanoi

[20] Hoang Minh Nguyen

Centre for Interdisciplinary Social Research, Phenikaa University, Hanoi

[42] Thai Vu Hong Nguyen

School of Business and Management, RMIT University Vietnam, Ho Chi Minh City

[52] Nhat Duc Nguyen

FPT School of Business (FSB), EPT University, Hanoi

[31] Thang Van Nguyen Asia Pacific Institute of Management, National Economics University, Hanoi

[44] Binh Nguyen Thanh School of Business and Management, RMIT University Vietnam, Ho Chi Minh City

[40] La Viet Phuong Centre for Interdisciplinary Social Research, Phenikaa University, Hanoi

[47] Tuan Huu Tran

[37] Thu-Trang Vuong

Centre for Interdisciplinary Social Research, Phenikaa University, Hano

[45] Shahab Shamshirband Sr.

Department of Management of Sciences and Technology Development, Ton Duc Thang University, Ho Chi Minh City

[54] Selim Ergun

School of Business and Management, RMIT University Vietnam, Ho Chi Minh City

[55] Chuc Dinh Nguyen Institute of Regional Sustainable Development, Vietnam Academy of Social Sciences, Hanoi

[39] Anh The Vo Business and Economics Research Group, Ho Chi Minh City Open University, Ho Chi Minh City 

respective publishers. 